\title{
Effect of Institutional and Insider Ownership on Dividend Policy: Evidence from Pakistan
}

\author{
RIFFAT SHAHEEN \\ IBMS, The University of Agriculture, Peshawar, Pakistan \\ shaheenriffatms13@gmail.com \\ DR. SABEEH ULLAH \\ IBMS, The University of Agriculture, Peshawar, Pakistan \\ sabeeh@aup.edu.pk
}

\begin{abstract}
This research study aimed to examine the effect of institutional and insider ownership on dividend policy of a firm. Ownership structure play a vital role in explaining firm dividend policy. To investigate the effect of institutional and insider ownership on dividend policy, a random sample of 50 non-financial firms was selected for the period of 2009 to 2013. The study based on panel data so for the selection of appropriate panel data model among pooled OLS, Random effect and Fixed effect, Breusch Pagan LM test, Chow test, and Hausman test were used and random effect model was found best fitted. Results indicated that institutional ownership has positive relationship while insider ownership has negative relationship with dividend payout. Further, inclusion of institutional ownership along with insider ownership has increased the explanatory power of the model by $5.56 \%$ which is the incremental effect of the institutional ownership. Moreover, free cash flows and leverage have negative while firm size and market to book value have positive relationship with dividend payout.
\end{abstract}

Keywords: Dividend policy, Institutional Ownership, Insider Ownership, Agency Theory, Pakistan

\section{Introduction}

Dividends are defined as circulation of a company's profit to its shareholders in proportion to their share in the company. Among corporate financial policies, dividend policy has an issue of greater attention in the area of corporate finance. Financial researchers have a general argument that declaration and payment of dividends are considered as a sign of financial growth and appreciation by investors while cuts in dividends are conceived as a decrease in financial growth and bad news for investors. In this way, dividend policies affect firm value. The debate on dividend policy was emerged with the work of (Modigliani \& Miller,1958; Miller \& Modigliani, 1961) who proposed dividend irrelevance theorem. They argued that even in perfect capital market the distribution of dividends does not affect shareholders wealth and because of which the firm value remains independent before and after dividend period. This situation of dividend irrelevancy leads to investors' dissatisfaction resulting in selling or buying of shares. Therefore, dividend policy seemed to have no advantage that firm might choose, and investors seemed indifferent of receiving capital gain and dividends. On the other hand, Gordon (1963) argued that even in a prefect capital market, the market value of the firm is affected 
by firm's dividend policy. Dividend policy of a firm depends on its investment policy, so dividend irrelevancy theorem is not valid (Krainer, 1971). Dividends communicate relevant information to the investors due to signaling or informational effect (Watts, 1973; Hakansson, 1982; Nissim \& Ziv, 2001). Sometimes investors ignore even large capital gain for current dividends (Gordon, 1959; Bhattacharya, 1979). Through changes in dividend payout policy investors can also obtained information about future earnings (Benartzi et al., 1997). Based on these arguments, corporate dividend policy is still a puzzle and mysterious problem in the field of corporate finance due to controversy in both dividends irrelevancy and relevancy theory.

Investors and shareholders have special value for dividends because corporate dividend decisions affect the firm value. Nevertheless, the reason for adoption of a dividend policy is the main problem for the firm, as dividend policy decisions depend on several factors e.g. profitability, taxation, liquidity, culture etc. Firm size is another important factor of dividend policy because large size firms have greater capability to pay more dividends due to their greater access to capital market. Moreover, there is a separation of control and ownership in large size firms because dividends provide monitoring benefits in these firms. Apart from above mentioned factors, firm dividend policy is highly dependent on ownership structure. Since in last few decades, corporate governance has received greater importance in corporate finance literature due to financial scandals i-e conflict of interest among shareholders and managers (Gillan \& Starks, 2003). One of the reasons for conflict is that there are different types of ownership and their demands for dividends in the firm. Insider and institutional ownership have greatest influence on firms' financial policies (Mehrani et al., 2011). From perspective of agency theory, dividend policy can act as a tool for resolving conflicts among shareholders and managers (Rozeff, 1982; Jensen, 1986). They argued that if funds are not paid as dividends to shareholders then managers might utilize these funds for their own benefits. Moreover, they might reinvest these funds in some unhealthy projects. On the other hand, payment of dividends to shareholders help in reducing managerial control and power over firm resources and restricting managers to the goal of maximizing firm value. This results in lowering agency conflicts between both parties. From ownership perspective, high level of insider ownership mitigates agency conflicts through interest alignment between both parties. But it also influences the dividend policy by using funds for their own interest and reducing dividend payment to minority shareholders which results in creating new conflicts of interest (Mirza \& Afza, 2010).

From above discussion about corporate dividend decision and ownership structure, it is concluded that dividends can be used as a mean of reducing conflicts whereas if managers have more control and power then they will expropriate the minority shareholders wealth by reducing dividend payouts. However, literature also suggested that only dividend is not a single tool of reducing the agency conflicts in term of costs and effect of these conflicts on firm value. Additionally, to dividend, large insider and institutional shareholders are also expected to help in interest alignment between managers and shareholders. Therefore, corporate dividend decisions anticipated to be affected by the ownership structure. Prior literature mainly documented the 
relationship of dividend policy with ownership structure in developed economies. But the nature, characteristics and efficiency of dividend policy and ownership structure in developing economies are different from those in developed economies (Abdulsalam et al., 2008). Therefore, it is likely that in developing countries, the relationship among ownership structure and dividend policy to be different from those of developed countries. In Pakistan, after introduction of Corporate governance codes in 2002, researchers' interest in dividend policy and ownership structure has been increased but still there are many issues to be explore (Rafique, 2012). Researchers mostly focused on determinants of dividend policy. Only few research studies attempted to investigate the relationship of dividend paying behavior of the firms with ownership structure but with a special focus on managerial ownership. Keeping this in view, and in addition to insider ownership, institutional ownership also has significant effect on dividend decisions. So, there is a need to analyze the effect of insider as well as institutional ownership on dividend policy and to check whether institutional ownership has any incremental effect.

\section{Literature Review}

Corporate financial policies are significantly influenced by ownership structure. In prior literature, the issue of ownership structure and dividend policy has received huge attention of researchers. The contemporary literature on the relationship of ownership structure and dividend policy can be distinguish into main two research trends. In first, researchers investigated the connection among institutional ownership and dividend policy, while in second the researchers linked insider ownership with dividend policy.

\subsection{Institutional Ownership and Dividend Policy}

Institutional ownership refers to the percentage of the firm's shares owned by institutions. Firms may have to change their behavior and policies due to existence of these institutional investors. Among these policies, shareholders deemed dividends as a reward for bearing risk and contributing in firms fund raising. Therefore, dividend policy used as tool for distributing firm's profit among its shareholders as a reward for their investment. Hence, firm growth as well as shareholders satisfaction badly affected by a minor mistake in formulating dividend policies (Ullah et al., 2012). Many studies have considered the relationship of dividend policy with ownership structure. Most of these studies found a positively significant connection among dividend policy and institutional ownership while negative relation with managerial ownership (Short et al., 2002). Many different theories can explain the link among dividend policy and institutional ownership. Out of these the most relevant and commonly used theories are agency theory and signaling theory.

\subsubsection{Agency Theory}

Agency theory of Jensen and Meckling (1976), states that the agency relationship arises when a contract is made between agent and principal in which the agent promise to perform some work on behalf of principal and principal promise to compensate agent for that work. Conflicts of interest arise when agents favor their personal interest over principals' interest or when there is a decrease in flow of information from agent to principal. These conflicts make agency relationship inefficient which resultantly creates agency cost. For agency cost, dividend policy is used as a tool for mitigating it (Rozeff, 1982). Conflict of interest could also result from dividend payments, as mangers prefer to retain earnings over paying dividends to shareholders for the purpose to increase their control and power over firm resources through following firm's growth strategy. On the other hand, shareholders 
demand dividend payments instead of retaining firm's profit. Therefore, Wiberg, (2008) suggested that while examining the dividend policy, it is critical to consider the role of institutional and other ownership structures.

Based on these arguments, it is concluded that by paying dividends, agency cost can be reduced in the following ways. First, when dividends are paid it reduces free cash flows problems. Second, it obliges managers to generate more cash for dividend payments and finally dividend payments force managers to concern capital market for raising future funds which in turn increase the provision of information to market (Laporta et al., 2000), and lessen the agency cost linked with free cash flows. Jensen (1986) free cash flow hypothesis documented that managers attempt to reduce dividend payments to increase their discretionary funds. Distribution of free cash flows in dividends is at priority list of institutional shareholders (Eckbo \& Verma, 1994). There are bundles of empirical research studies undertaken by (Han et al., 1999; Wang et al., 2011; Zeckhauser \& Pound, 1990) that provided evidence on positive role of institutional shareholders in solving agency problems through their influence on agency cost and dividend policy. Furthermore, Short et al., (2002); Wiberg, 2008; Truong and Heaney (2007) documented a positive relation between institutional ownership and dividend policy. Hence, based on agency theory and the empirical work, the study hypothesizes as:

Hla: There exist a positively significant association among dividend policy and institutional ownership.

\subsubsection{Signaling Theory}

Signaling theory states that information asymmetry exists between shareholders and company management because managers have more access to company's information than outside stockholders and are not provide to them with transparent way. In order to convey information to outside shareholders, managers use some reliable measure like dividend policy. Therefore, dividend policy can be utilized to signal information about firm's future earnings (Pettit, 1972; Ofer \& Thakor, 1987; Robinson, 2006). Zeckhauser and Pound (1990) proposed that along with dividends, institutional shareholders might act as alternative tool of signaling because they can significantly influence the firm performance. Under this, a negative relation is projected among institutional ownership and dividend policy. However, it is still unclear from the available literature that how institutional shareholders signal firm's future growth to the market. This signaling is possible in two ways; first, the institutional shareholders, due their access and control, are likely to have superior information about firm's future growth. Therefore, the presence of institutional shareholders may consider as a signal of good news about firms' future growth. Second, the market may consider the existence of institutional shareholders as a signal of agency cost reduction due to institutional shareholders' monitoring. However, institutional shareholders do not consider themselves as an alternative signaling device as they emphasize on dividends as a signal of firm future growth. Therefore, the argument that institutional shareholders and dividend payouts are alternative signaling tool appears less convincing (Short et al., 2002). Additionally, Kouki and Guizani (2009); Jain (2007) reported negatively significant connection among dividend policy and institutional ownership. Jensen et al., (1992) also supported negatively significant connection between dividend payments and institutional ownership. Summarizing the above discussion on signaling theory, the study hypothesizes as:

HIb: There is significantly negative relation among institutional ownership and dividend policy. 


\subsection{Insider Ownership and Dividend Policy}

A large body of literature exists on the connection among insider ownership and corporate dividend policy (Mehrani et al. 2011). Studies undertaken by Jensen and Thomas (1992); Short et al., (2002); Amitabh and Fairleigh (1999); Abdullah et al. (2012); Rozeff (1982) reported a negatively significant influence of managerial ownership on dividend policy. In addition, Al-Gharaibeh et al., (2013) investigated the dividend relationship with ownership structure by considering 35 Jordanian firms over a period of 2005 to 2010 . They found that if the institutional ownership in a firm increases then it will increase the firm value by increasing the power and control of these shareholders. Further, they also found negatively significant coefficient of managerial ownership with dividend policy. Azfa and Mirza (2010) concluded that managerial ownership and individual ownership have negative relation with cash dividend. Furthermore, studies conducted by Din and Javid (2011); Eckbo and Verma (1994); Chen et al. (2005); Wen and Jia (2010); Mehrani et al. (2011) found that dividend payouts have a significant and negative association with managerial ownership. Based on the findings of these prior studies, it is hypothesized as:

H2: There exist significantly negative link among between insider ownership and dividend policy.

\section{Research Methodology}

To test the relationship of dividend policy with ownership structure, a sample of 50 non-financial firms was randomly selected for the collection of annual data over a period of 2009 to 2013. Firms having negative equity value and firms having missing data were excluded. The study was based on panel data which was collected through secondary sources. Further, data of all the variables other than ownership structure obtained from the Balance Sheet Analysis (BSA) issued by State Bank of Pakistan while ownership variables calculated from the pattern of shareholding statement of the selected firms. Three categories of variables including dependent, independent and control variables were used, which were defined in Table 1 . Since the study used panel data so for analysis, pooled OLS and panel data models (fixed effect and random effect) were taken into consideration. To decide among these models' different diagnostic tests including Chow test, Breusch pagan LM test and Hausman specification test were performed.

Table 1 Variables of the study

\begin{tabular}{|c|c|c|c|}
\hline Variables & Definition & Proxy used by & Sources \\
\hline $\begin{array}{l}\text { Dividend } \\
\text { payout } \\
\text { (DPO) }\end{array}$ & $\begin{array}{l}\text { cash dividend per } \\
\text { share divided by } \\
\text { earnings per share }\end{array}$ & $\begin{array}{l}\text { Rozeff (1982); } \\
\text { Moh'd et al., } \\
\text { (1995); Manos } \\
\text { (2002); Mollah et } \\
\text { al., (2007) }\end{array}$ & $\begin{array}{l}\text { BSA } \\
\text { SBP }\end{array}$ \\
\hline $\begin{array}{l}\text { Institutional } \\
\text { ownership } \\
\text { (IO) }\end{array}$ & $\begin{array}{l}\text { Shares held by } \\
\text { institutional } \\
\text { investors to total no. } \\
\text { of shares } \\
\text { outstanding }\end{array}$ & $\begin{array}{l}\text { Jensen \& Thomas, } \\
\text { (1992); Szilagyi \& } \\
\text { Renneboog, (2007) }\end{array}$ & $\begin{array}{l}\text { Annual } \\
\text { Report }\end{array}$ \\
\hline $\begin{array}{l}\text { Insider } \\
\text { ownership } \\
\text { (IS) }\end{array}$ & $\begin{array}{l}\text { shares held by } \\
\text { managers, BOD, } \\
\text { executives and their } \\
\text { families to total }\end{array}$ & $\begin{array}{l}\text { Crutchley \& } \\
\text { Hansen, (1989); } \\
\text { Mahadwartha, } \\
\text { (2003) }\end{array}$ & $\begin{array}{l}\text { Annual } \\
\text { Report }\end{array}$ \\
\hline
\end{tabular}




\begin{tabular}{llll}
\hline & $\begin{array}{l}\text { number of shares } \\
\text { outstanding }\end{array}$ & & \\
Free cash & $\begin{array}{l}\text { cash flow from } \\
\text { flows (FCF) }\end{array}$ & $\begin{array}{l}\text { (Kouki and Guizani } \\
\text { operations minus }\end{array}$ & Annual \\
& 2009) & Report \\
& to total assets & & \\
\hline
\end{tabular}

Table 1 Continued...

\begin{tabular}{|c|c|c|c|}
\hline $\begin{array}{l}\text { Firm } \\
(\mathrm{FS})\end{array}$ & $\begin{array}{l}\text { Natural logarithm of } \\
\text { total assets }\end{array}$ & $\begin{array}{l}\text { Gugler and } \\
\text { Yurtuglu 2003; } \\
\text { (Fama and French } \\
2001 \text { ) }\end{array}$ & $\begin{array}{l}\text { Annual } \\
\text { Report }\end{array}$ \\
\hline $\begin{array}{l}\text { Leverage } \\
\text { (LEV) }\end{array}$ & $\begin{array}{l}\text { long term debt/ total } \\
\text { assets }\end{array}$ & $\begin{array}{l}\text { Al Kuwari 2009); } \\
\text { Gugler and } \\
\text { Yurtoglu } 2003\end{array}$ & $\begin{array}{l}\text { Annual } \\
\text { Report }\end{array}$ \\
\hline $\begin{array}{l}\text { Market to } \\
\text { book value } \\
(\mathrm{MTBV})\end{array}$ & $\begin{array}{l}\text { Total market } \\
\text { capitalization to book } \\
\text { value of equity }\end{array}$ & $\begin{array}{l}\text { Gul 1999; La } \\
\text { Porta et al. } 2000\end{array}$ & $\begin{array}{l}\text { Annual } \\
\text { Report }\end{array}$ \\
\hline
\end{tabular}

To achieve the study objectives, first, model was used to analyze the effect of institutional ownership on dividend policy along with other control variables including free cash flows, leverage, firm size and market to book value. Model for dividend policy and institutional ownership were as:

$$
\mathrm{DPO}_{\text {it }}=\beta_{0}+\beta_{1} \mathrm{IO}_{\mathrm{it}}+\beta_{2} \mathrm{FCF}_{\mathrm{it}}+\beta_{3} \mathrm{FS}_{\mathrm{it}}+\beta_{4} \mathrm{LEV}_{\mathrm{it}}+\beta_{5} \mathrm{MTBV}_{\mathrm{it}}+\varepsilon_{\mathrm{it}}
$$

Second, for the effect of insider ownership on dividend policy after controlling for same variables, second model was used which is given as follows:

$\mathrm{DPO}_{\mathrm{it}}=\beta_{0}+\beta_{1} \mathrm{IS}_{\mathrm{it}}+\beta_{2} \mathrm{FCF}_{\mathrm{it}}+\beta_{3} \mathrm{FS}_{\mathrm{it}}+\beta_{4} \mathrm{LEV}_{\mathrm{it}}+\beta_{5} \mathrm{MTBV}_{\mathrm{it}}+\varepsilon_{\mathrm{it}}$

Third, for the effect of both institutional and insider ownership on dividend policy, the model used was:

$\mathrm{DPO}_{\text {it }}=\beta_{0}+\beta_{1} \mathrm{IO}_{\text {it }}+\beta_{2} \mathrm{IS}_{\text {it }}+\beta_{3} \mathrm{FCF}_{\mathrm{it}}+\beta_{4} \mathrm{FS}_{\mathrm{it}}+\beta_{5} \mathrm{LEV}_{\mathrm{it}}+\beta_{6} \mathrm{MTBV}_{\mathrm{it}}+\varepsilon_{\mathrm{it}}$

Where;

$\beta_{0}=$ intercept of the regression model

$\beta_{1}, \beta_{2}, \beta_{3}, \beta_{4}, \beta_{5}, \beta_{6}=$ slope of the regression coefficients

$i=$ ith sample of non-financial firms

$\mathrm{t}=$ time period (2009-2013)

$\mathrm{DPO}=$ Dividend payout

IO = Institutional Ownership

IS = Insider Ownership

$\mathrm{FCF}=$ Free cash Flows

FS $=$ Firm Size

LEV = Leverage

MTBV $=$ Market to Book Value 


\section{Results and Discussion}

To analyse the data of 50 companies for the period of 5 years (from 2009 to 2013), different tests were performed on the data. It includes descriptive statistics and panel data analysis for selection of appropriate regression model.

\subsection{Descriptive Statistics}

The Table 2 shows that there is reasonable difference between minimum and maximum values of all variables. Among all variables, firm size has the largest mean value of 17.946 whereas, insider ownership has the lowest mean value of 0.156 . The results also show that mean values of all variables except free cash flows, firm size and market to book value are closer to their standard deviation values which shows that these variables have low volatility and there is no data variability problem with these variables. On the other hand, free cash flows, firm size and market to book value have highest standard deviation values of $2.648,2.398$, and 1.275 respectively, which are considerably different from their mean values of 15.904, 17.946, and 0.555 which shows that these variables are volatile enough and have data variability problem.

Table 2 Descriptive Statistics

\begin{tabular}{llllll}
\hline \multicolumn{1}{c}{ Variables } & N & Min & Max & Mean & Std. Dev. \\
\hline DPO & 250 & 0.00 & 2.16 & 0.519 & 0.401 \\
IO & 250 & 0.00 & 0.665 & 0.168 & 0.169 \\
IS & 250 & 0.00 & 0.81 & 0.156 & 0.216 \\
FCF & 250 & 10.05 & 23.07 & 15.904 & 2.648 \\
FS & 250 & 14.46 & 24.6 & 17.946 & 2.398 \\
LEV & 250 & 0.00 & 0.85 & 0.167 & 0.177 \\
MTBV & 250 & 0.00 & 9.41 & 0.555 & 1.275
\end{tabular}

\subsection{Panel Data Model Identification Tests}

In order to decide whether the pooled OLS, Random effect or Fixed effect model is appropriate for the data, Breusch-Pagan LM test, Chow test, and Hausman test were performed.

Table 3 Panel Data Model Identification Tests

\begin{tabular}{|c|c|c|c|c|}
\hline Test & Model & Test value & $\begin{array}{l}\mathrm{P}- \\
\text { value }\end{array}$ & $\begin{array}{l}\text { Model } \\
\text { Selection }\end{array}$ \\
\hline Chow test & Pooled OLS vs Fixed effect & $\mathrm{F}=18.44$ & 0.000 & Fixed effect \\
\hline $\begin{array}{l}\text { Breusch } \\
\text { Pagan } \\
\text { test }\end{array}$ & $\begin{array}{l}\text { Pooled OLS vs Random } \\
\text { effect }\end{array}$ & $\begin{array}{l}\text { Chi-sq.= } \\
97.38\end{array}$ & 0.000 & $\begin{array}{l}\text { Random } \\
\text { effect }\end{array}$ \\
\hline $\begin{array}{l}\text { Hausman } \\
\text { Specification } \\
\text { test }\end{array}$ & $\begin{array}{l}\text { Random effect vs Fixed } \\
\text { effect }\end{array}$ & Chi-sq. $=8.26$ & 0.219 & $\begin{array}{l}\text { Random } \\
\text { effect }\end{array}$ \\
\hline
\end{tabular}




\subsection{Effect of Institutional Ownership on Dividend Policy}

Table 4 explains the relationship of institutional ownership with firm dividend policy. In which, the coefficient of institutional ownership is positively significant with dividend payout at $1 \%$ level of significance. It supports our hypothesis H1a that dividend payout ratio increases with the increase in institutional shareholders. This support the notion that institutional shareholders prefer payment of firm profit as dividend instead of retaining profit (Eckbo \& Verma, 1994) which resultantly help in reducing agency cost. The result is also in line with the results of (Short et al., 2002; Truong \& Heaney, 2007; Wang et al., 2011), who also reported that corporate dividend decisions have significant positive relation with institutional ownership.

For Control variables, free cash flows found to have significantly positive relationship with dividend payout. The research finding is supported by (Kouki \& Guizani, 2009; Mehrani et al., 2011) and the notion that increasing dividend with the increase in free cash flows help in reducing agency conflicts between managers and shareholders (Rozef 1982). Firm size is found to have negative regression coefficient with dividend payout, which is in line with the research findings of (Gugler \& Yurtuglu, 2003; Mirza \& Afza, 2010; Ullah et al., 2012). The negative relationship of firm size with dividend payout in context of Pakistan support the notion that instead of paying dividends, Pakistani firms prefer to invest funds in their projects (Ahmed \& Javid, 2008). Leverage have also negative regression coefficient with dividend payout. The result indicated that due to obligation of fixed interest payments and financial risk, highly leveraged firms are not willing to pay funds as dividends and attempt to reserve their funds to establish and maintain good political and social relations with financial institutions and strong credit rating in order to ensure the low cost future financing because Pakistani firms need to have strong relations and credit rating to get access to debt market for external financing (Ehsan et al., 2013). The results are also consistent with outcomes of (Fama \& French, 2001; Gugler \& Yurtoglu, 2003; Al-Kuwari, 2009). Finally, the coefficient of market to book value is significantly positive dividend payout. This result is consistent with the findings of (La Porta et al., 2000).

Table 4 Impact of Institutional Ownership on Dividend Policy

\begin{tabular}{lllll}
\hline Variables & Coefficients & Std. error & Z-statistics & P-value \\
\hline IO & 0.589 & 0.126 & 4.69 & $0.000^{* * *}$ \\
FCF & 0.044 & 0.013 & 3.45 & $0.001^{* * *}$ \\
FS & -0.050 & 0.018 & -2.72 & $0.006^{* *}$ \\
LG & -0.702 & 0.144 & -4.88 & $0.000^{* * *}$ \\
MTBV & 0.087 & 0.016 & 5.35 & $0.000^{* * *}$ \\
Constant & 0.679 & 0.260 & 2.61 & $0.009 * *$ \\
\hline
\end{tabular}

$\mathrm{R}^{2}=0.338 \quad$ F- Value $=119.00 * * *(\mathrm{p}$-value $=0.000)$

\subsection{Impact of Insider Ownership on Dividend Policy}

Table 5 explains the relationship of insider ownership with firm dividend policy. The results indicate that insider ownership is negatively associated with dividend payout ratio, which is consistent with the findings of (Jensen \& Thomas, 1992; Mahadwartha, 2003; Abdullah et al., 2012). The negative relation of insider ownership with 
dividend payout implies that managers are not willing to pay firm profits as dividends and attempt to increase their discretionary power by reducing dividend payments to minority shareholders (Eckbo \& Verma, 1994). In case of Pakistan, when insider ownership increases in the firm then managers try to take advantage of their power and control due to lack of proper supervision by regulatory authority and hence expropriate the benefits of minority shareholders by reducing dividend payments and using funds for personal benefits. Further, the results for all control variables are same as in Table 4.

Table 5 Impact of Insider Ownership on Dividend Policy

\begin{tabular}{lllll}
\hline Variables & Coefficients & Std. error & Z-statistics & P-value \\
\hline IS & -0.310 & 0.124 & -2.50 & $0.013^{* *}$ \\
FCF & 0.045 & 0.013 & 3.44 & $0.001^{* * *}$ \\
FS & -0.040 & 0.019 & -2.09 & $0.037^{*}$ \\
LG & -0.602 & 0.152 & -3.96 & $0.000^{* * *}$ \\
MTBV & 0.085 & 0.017 & 5.04 & $0.000^{* * *}$ \\
Constant & 0.617 & 0.272 & 2.26 & $0.024^{* *}$ \\
\hline
\end{tabular}

$\mathrm{R}^{2}=0.289 \quad$ F- Value $=97.42 * * *(\mathrm{p}$-value $=0.000)$

\subsection{Effect of Institutional and Insider Ownership on Dividend Policy}

Table 6 explains the relationship of both institutional and insider ownership with firm dividend policy. The findings indicate that both institutional and insider ownership have significant relationship with dividend payout. However, institutional ownership has positive while insider ownership has negative relationship with dividend payout. These results are in line with the results of institutional and insider ownership in Table 4 and 5 respectively and suggested that both institutional ownership and insider ownership have a significant role in explaining firm dividend policy. Hence institutional ownership has an incremental effect of $5.56 \%$ on the explanatory power of the model. Furthermore, results of all the control variables are same with the results in Table 4 and 5.

Table 6 Effect of Institutional and Insider Ownership on Dividend Policy

\begin{tabular}{lllll}
\hline DPO & Coefficients & Std. error & Z-statistics & P-value \\
\hline IO & 0.576 & 0.125 & 4.62 & $0.000^{* * *}$ \\
IS & -0.286 & 0.120 & -2.39 & $0.017^{* *}$ \\
FCF & 0.043 & 0.013 & 3.38 & $0.001^{* * *}$ \\
FS & -0.043 & 0.018 & -2.34 & $0.020^{* *}$ \\
LG & -0.629 & 0.146 & -4.30 & $0.000^{* * *}$ \\
MTBV & 0.085 & 0.016 & 5.25 & $0.000^{* * *}$ \\
Constant & 0.617 & 0.263 & 2.34 & $0.019^{* *}$ \\
\hline
\end{tabular}

$\mathrm{R}^{2}=0.345 \quad$ F- Value $=126.92 * * *(\mathrm{p}-$ value $=0.000)$ 


\section{Conclusion}

This research study was conducted to find out the role of ownership structure as one of most key factors of the corporate governance mechanisms in explaining the dividend paying behavior of firms in context of Pakistan. Findings of this research study indicate that both institutional and insider ownership have significantly positive and negative association with dividend payout respectively. The results also revealed that inclusion of institutional ownership has improved the explanatory power of the model by $5.56 \%$ which is the incremental effect of the institutional ownership. Based on findings, it is concluded that ownership structure plays a vital role in determining the dividend paying behavior of the firm especially in context of agency relation and hence help in reducing agency cost. In Pakistan, most of the firms are family controlled and don't support the implementation of corporate governance mechanism. In these firm's insider shareholders get favor and keep wealth of the firm under their control that leads to minority shareholders expropriation. Due to high family ownership most of firms either don't pay dividends or pay dividend but at low rate and irregularly. Therefore, institutional shareholders due to low legal protection and negligible control, prefer dividend payment to control the opportunistic behavior of insiders and hence help in reducing agency conflicts.

\section{References}

Abdullah, N, M, H., Z. Ahmad., \& S. Roslan. (2012). The Influence of Ownership Structure on the Firms Dividend Policy Based Lintner Model. Int. Rev. Bus.

Res.Papr.,8(6),71 - 88

Abdulsalam, O., A. El-Masry., \& S. Elsegini. (2008). Board composition, ownership structure and dividend policies in an emerging market. Manage. Financ., 34(12), 953-964.

Ahmed, H., \& A.Y. Javid. (2008). Dynamics and determinants of dividend policy in Pakistan (Evidence from Karachi stock exchange non-financial listed firms). Munich Personal RePEc Archive, pp, 15.

Al- Gharaibeh, M., Z. Zurigat., \& K. Al-Harahsheh. (2013). The Effect of Ownership Structure on Dividends Policy in Jordanian Companies. Intrdiscp. J. Con. Res. Bus., 4(9), 769-796.

Al-Kuwari, D. (2009). Determinants of the Dividend Policy in Emerging Stock Exchanges: The Case of GCC Countries. G. Econ. \& Financ. J., 2(2), 38-63.

Amitabh., \& Fairleigh. (1999). Managerial Ownership, Dividend and Debt Policy in theUS Banking Industry. Manage. Financ., 25(6),57.

Benartzi, S., R. Michaely., \& R, Thaler. (1997). Do Changes in Dividends Signal the Future or Past? J. Financ., 52 (3), 1007-1034.

Bhattacharya, S. (1979). Imperfect Information, Dividend Policy, and 'the Bird-inHand' Fallacy. Bell. J. Econ., 10 (1), 259-270.

Chen, Z., Y.L. Cheung., A. Stouraitis., \& A.W.S .Wong. (2005). Ownership Concentration, Firm Performance and dividend policy in Hong-Kong. J. Bas. Financ., 13, 431-449.

Crutchley, C., \& R. Hansen. (1989). A Test of the Agency Theory of ManagerialOwnership, Corporate Leverage and Corporate Dividends. Financ. Mgt., 18(4), 36-46. http://dx.doi.org/10.2307/3665795

Din, S., \& A.Y. Javid. (2011). Impact of Managerial Ownership on Financial Policies and the Firm's Performance: Evidence Pakistani Manufacturing Firms. Int. Res. J. Financ. Econ., pp: 81. 
Eckbo, B.E., \& S. Verma. (1994). Managerial Share ownership, Voting power, and Cash Dividend Policy. J. Corp. Financ., 1, 33-62.

Fama, E., \& K. French. (2001). Disappearing dividends: changing firm characteristics orlower propensity to pay? J. Financ. Econ., 60, 3-43.

Gillan, S.L., \& L.T. Starks. (2003). Corporate Governance, Corporate Ownership, and the Role of Institutional Investors: A Global Perspectives. J. Appl. Financ., 13(2), 422.

Gordon, M. J. (1959). Dividends, Earnings and Stock Prices. Rev. Econ. Stat., 41 (2), 99-105.

Gordon, M. J. (1963). Optimal Investment and Financing Policy. J. Financ., 18 (2), 264-272.

Gugler, K.,\& B.B. Yurtoglu. (2003). Corporate governance and dividend payout policy in Germany. Eur. Econ. Rev., 47, 731-758.

Gul, F. (1999). Growth opportunities, capital structure and dividend policies in Japan. J.Corp. Financ., 5, 141-168.

Hakansson, N. H. (1982). To Pay or Not to Pay Dividend? J. Financ., 37 (2), $415-$ 428.

Han, K.C., S. H. Lee., \& D. Y. Suk. (1999). Institutional Shareholders and Dividends. J.Financ., 12(1), 53-62.

Jain, R. (2007). Institutional and individual investor preferences for dividends and share repurchases. J. Bus. Econ., 59, 406-429.

Jensen, M. (1986). Agency costs of free-cash-flow, corporate finance, and takeovers. Am. Econ. Rev., 76, 323-329.

Jensen, M.C., \& W. H. Meckling. (1976). Theory of the Firm: Managerial Behavior, Agency Costs, and Ownership Structure. J. Financ. Econ., 3, 305-360.

Jensen,. \& Thomas. (1992). Simultaneous Determination of Insider Ownership, Debt, and Dividend Policies. J. Financ. Quant. Anal., pp: 247-263.

Jensen, G., D.P. Solberg., \& T.S. Zorn. (1992). Simultaneous determination of insider ownership, debt, and dividend policies. J. Financ. Quant. Anal., 27, 247-263.

Kouki, M., \& M. Guizani. (2009). Corporate Governance and Dividend Policy in Poland. Warsaw School of Economics, World Economy Research Institute, Al. Niepodlegosci Warsaw, Poland, 162, 02-554.

Krainer, R. E. (1971). A Pedagogic Note on Dividend Policy. J. Financ. Quant. Anal., 6 (4), 1147-1154.

LaPorta, R., F. L. Desilanes., A. Shleifer., \& R. W. Vishny.(2000). Agency problems and dividend policies around the world. J. Financ., pp: 55: 1-33.

Mahadwartha, P.A. (2003). Predictability Power of Dividend Policy and Leverage Policyto Managerial Ownership: An Agency Theory Perspective. J. Econ. Bus. Indo., 18(3), 1-20.

Mehrani, S., M. Moradi., \& H. Eskandar. (2011). Ownership Structure and Dividend Policy: Evidence from Iran. Afr. J. Bus. Mgt., 5(17), 7516-7525.

Miller, M.H. \& F. Modigliani, (1961). Dividend firm's performance. The dividend policyis mutually policy, growth and the valuation of shares. J. Benef. Firm. Invest. Gro.Bus., pp: 411-433.

Moh'd, M.A., L.G. Perry., \& J.N. Rimbey. (1995). An investigation of the dynamic association between agency theory and dividend policy. Financ. Rev., 30 (2),367385. 
Mollah, A.S, R.B. Rafiq., \& P.A. Sharp (2007). Relevance of agency theory for dividendpolicy in an emerging economy: The case of Bangladesh. IFCAI. $J$. Appl.Financ., 13, 5-15.

Manos, R. (2002). Dividend policy and agency theory: Evidence on Indian firms. Finance and development research program, working paper series, 41, 1-25.

Mirza, H., \& T. Afza (2010). Ownership structure and cash flows as determinants of corporate dividend policy in Pakistan. Int. Bus. Res., 3(3), 210-221.

Modigliani, F., \& M.H. Miller. (1958). Dividend Policy, Growth, and the Valuation of Shares. Am. Econ. Rev., 48 (3), 261-297.

Nissim, D., \& A. Ziv. (2001). Dividend Changes and Future Profitability. J. Financ., 56 (6), 2111-2133.

Ofer, A.R., \& A.V. Thakor. (1987). A Theory of Stock Price Responses to Alternative Corporate Cash Disbursement Methods: Stock Repurchases and Dividends. J. Financ., 42, 889-911.

Pettit, R. (1972). Dividend Announcement, Security Performance, and Capital Market Efficiency. J. Financ., 11, 993-1007.

Rafique, M. (2012). Factors Affecting Dividend Payout: Evidence from Listed NonFinancial Firms of Karachi Stock Exchange. Bus. Mgt. Dynam., 1(11), 76-92.

Robinson, J. (2006). Dividend policy among publicly listed firms in Barbados. J. East. Caribb. St., 31, 1-36.

Rozeff, M.S. (1982). Growth, Beta and Agency Costs as Determinants of Dividend Payout Ratios. J. Financ. Res., 5(3), 249-259.

Short, H., H. Zhang., \& K. Keasey. (2002). The link between dividend policy and institutional ownership. J. Corp. Financ., 8, 105-122.

Szilagyi, P. G., \& L. Renneboog. (2007). How relevant is dividend policy under lowshareholder protection? Working paper, University of Cambridge and Tilburg University.

Truong, T.H., \& R. Heaney. (2007). Largest Shareholder and Dividend Policy around the World. Q. Rev. Financ. Econ., 47, 667-687.

Ullah, H,. A.Fida., \& S. Khan. (2012). The Impact of Ownership Structure on DividendPolicy Evidence from Emerging Markets KSE-100 Index Pakistan, Int. J. Bus. Social. Sci., 3(9), 298-307

Wang, X., D. Manry., \& S. Wandler. (2011). The impact of government ownership on dividend policy in China. Advances in Accounting, incorporating Advances in International Accounting. article in Press.

Wen, Y,. \& J. Jia. (2010). Institutional Ownership, Managerial Ownership and Dividend Policy in Bank Holding Companies. Int. Rev. Account. Bank. Financ., 2( 1), 8-21.

Watts, R. (1973). The Information Content of Dividends. J. Bus., 46 (2), 191-211.

Wiberg, D. (2008). Ownership, Dividends, R\&D and Retained Earnings: are institutional owners short-term oriented? Working paper. The Royal Institute of technology. Centre of Excellence for Science and Innovation Studies (CESIS).

Zeckhauser, R. J., \& J. Pound. (1990). Are Large Shareholders Effective Monitors? An Investigation of Share Ownership and Corporate Performance. University of Chicago Press. pp: 149-180. 